\title{
PEMANFAATAN LINGUISTIK HISTORIS KOMPARATAIF DALAM PEMETAAN BAHASA-BAHASA NUSANTARA
}

\author{
La Ino \\ Universitas Halu Oleo
}

\begin{abstract}
Abstrak
Linguistik Historis Komparatif sebagai salah satu cabang linguistik mempunyai tugas utama, antara lain menetapkan fakta dan tingkat keeratan dan kekerabatan antarbahasa yang berkaitan erat dengan pengelompokan bahasa-bahasa sekerabat. Penelitian sejarah bahasa adalah mencari hubungan yang ada di antara bahasa-bahasa dan merekonstruksi bahasa-bahasa proto yang telah menurunkan bahasabahasa yang ada pada saat ini. Pembuktian hubungan kekerabatan dan keseasalan itu pada umumnya bertolak dari pengelompokan bahasa-bahasa dan rekonstruksi protobahasanya. Pengelompokan adalah penentuan bahasa-bahasa dalam suatu susunan atau protokerabat (family tree). Selanjutnya rekonstruksi protobahasa adalah penetapan satuan-satuan kebahasaan sebagai protobentuk. Dengan demikian, melalui pengelompokan dan rekonstruksi dapat diperoleh kejelasan hubungan kekerabatan dan keseasalan sesuai dengan jenjang struktur dan silsilah kekerabatan bahasa .
\end{abstract}

Kata Kunci: Linguistik Historis Komparatif

\begin{abstract}
Historical Comparative Linguistics as a branch of linguistics has primary responsibility, among others, establish the facts and the level of closeness and kinship closely inter-related with the grouping of languages. Research the history of the language is to find relationships that exist between languages and to reconstruct proto-languages which have lowered the languages that exist at the moment. Proof of kinship and origin it generally depart from the grouping of languages and protolanguage reconstruction. Grouping is the determination of the languages in an arrangement or family tree. Furthermore proto-language reconstruction is the determination of linguistic units as prototype. Thus, through grouping and reconstruction can be obtained clarity kinship and origin in accordance with the level of structure and pedigree kinship language.
\end{abstract}

Keywords: Historical Comparative Linguistics

\section{PENDAHULUAN}

\section{Linguistik Historis Komparatif} sebagai salah satu cabang linguistik mempunyai tugas utama, antara lain menetapkan fakta dan tingkat keeratan dan kekerabatan antarbahasa yang berkaitan erat dengan pengelompokan bahasa-bahasa sekerabat. Bahasa-bahasa sekerabat yang termasuk dalam anggota suatu kelompok bahasa pada dasarnya memiliki sejarah perkembangan yang sama. Sesuai dengan tugas utama tersebut, linguistik historis komparatif memiliki kewenangan dalam mengkaji relasi historis di antara kelompok bahasa tertentu (Antilla, 1972:20).

Penelitian sejarah bahasa adalah mencari hubungan yang ada di antara bahasabahasa dan merekonstruksi bahasa-bahasa proto yang telah menurunkan bahasabahasa yang ada pada saat ini. Pembuktian hubungan kekerabatan dan keseasalan itu pada umumnya bertolak dari pengelompokan bahasa-bahasa dan rekonstruksi protobahasanya. Pengelompokan adalah 
penentuan bahasa-bahasa dalam suatu susunan atau protokerabat (family tree). Selanjutnya rekonstruksi protobahasa adalah penetapan satuan-satuan kebahasaan sebagai protobentuk. Dengan demikian, melalui pengelompokan dan rekonstruksi dapat diperoleh kejelasan hubungan kekerabatan dan keseasalan sesuai dengan jenjang struktur dan silsilah kekerabatan bahasa (Antilla. 1972:29; Hock, 1988:567)

Penelitian ini dilandasi oleh teori linguistik historis komparatif. Teori ini dikembangkan antara lain oleh Jacob Grimm (1787-1863), Lehman (1972), Hock (1988), Bynon (1979). Teori ini disebut juga teori diakronik, yaitu menyangkut analisis bentuk dan keteraturan perubahan bahasa-bahasa umum misalnya yang dilengkapi dengan perubahan bunyi, untuk merekonstruksi bahasa masa lalu, yaitu bahasa purba (proto) yang hidup pada ribuan tahun sebelum itu. Bahasa purba (proto) ini berubah dan pecah menjadi beberapa bahasa turunan karena factor tempat dan waktu (Bynon, 1979:54). Bahasa-bahasa turunan ini mewarisi kaidah-kaidah bahasa asalnya dan akan berbeda karena perkembangan (inovasi) yang terjadi belakangan setelah bahasa itu berbeda (Bynon, 1979:61).

Hubungan kekerabatan antar bahasa serumpun dalam kajian komparatif pada dasarnya dapat dibuktikan berdasarkan unsur-unsur warisan dari bahasa asalnya atau proto bahasa (Hock, 1988). Konsep bahasa asal atau proto bahasa sesungguhnya bukanlah merupakan wujudnya tabahasa, melainkan suatu bentuk yang dirancang bangun atau dirakit kembali sebagai gambaran tentang masalalu suatu bahasa. Dengan kata lain, konsep ini merupakan gagasan teoretis yang dirancang dengan cara yang amat sederhana guna menghubungkan sistem-sistem bahasa sekerabat dengan menggunakan sejumlah kaidah (Jeffers dan Lehiste, 1970; Bynon:1979:71). Fakta-fakta kebahasaan dalam wujud keteraturan, kesepadanan yang ditemukan pada bahasa-bahasa kerabat menunjukkan bukti adanya keaslian bersama yang terwaris dari moyang yang sama (Bynon, 1979:47). Dengan adanya ciri-ciri warisan yang sama, keeratan hubungan keseasalan antara bahasa-bahasa kerabat dapat ditemukan dan system proto bahasanya dapat dijejaki.

Pengelompokan berarti penentuan silsilah kelompok bahasa demi kejelasan struktur genetisnya. Dengan pengelompokan, setiap bahasa yang diperbandingkan dapat diketahui kedudukan dan hubungan keseasalannya dengan bahasabahasa kerabat lainnya. Dilain pihak, rekonstruksi protobahasa memperjelas hubungan kekerabatan dan ikatan keseasalan bahasa-bahasa itu sesuai jenjang kekerabatan yang dapat disilsilahkan. Hal itu 
mengandung makna, protobahasa sebagai suatu sistem yang diabstrasikan dari wujud bahasa-bahasa kerabat merupakan pantulan kesejarahan bahwa bahasa-bahasa itu pernah mengalami perkembangan yang sama sebagai bahasa tunggal (Antilla, 1972:213).

Rekonstruksi protobahasa berpijak pada dua hipotesis, yakni hipotesis keterhubungan dan hipotesis keteraturan (Jeffers dan Lehiste, 1979:17; Hock, 1988:567). Ciri umum yang dimiliki hipotesis keterhubungan ini adalah kemiripan dan kesamaan wujud kebahasaan. Salah satu ciri yang paling diandalkan adalah kemiripan bentuk dan makna kata-kata. Kata-kata yang memiliki kemiripan atau kesamaan bentuk dan makna yang biasa disebut kosa kata seasal (cognate set) bukan sebagai pinjaman, kebetulan, atau kecenderungan semesta, tetapi dihipotesiskan sebagai warisan dari asal-usul yang sama. Hipotesis keteraturan berwujud perubahan bunyi yang bersistem dan teratur pada bahasa-bahasa turunan. Sebuah segmen bunyi dari proto bahasa yang terwaris melalui kosakata seasal berubah secara teratur pada suatu bahasa turunan.

Penelusuran terhadap unsur warisan bahasa berkerabat meliputi tataran leksikal, fonologi, morfologi, dan sintaksis. Dalam studi komparatif, tataran leksikal dan fonologi lebih umum dipakai sebagai dasar penentuan kekerabatan dan pengelompokan bahasa serumpun dengan alasan sebagai berikut. Pertama, melalui pengelompokan leksikal, kita bisa memperoleh informasi tentang budaya, sejarah, kehidupan sosial, dan fakta-fakta geografis suatu masyarakat bahasa. Kedua, pengelompokan yang paling berhasil pada studi komparatif adalah pengelompokan pada tataran fonologis karena berbagai faktor: (a) segmen atau unsur fonologis merupakan unsur terkecil dalam suatu bahasa, dengan demikian lebih mudah dipahami; (b) lebih mudah ditemukan fakta yang relevan dibandingkan tataran lainnya. Karena sebuah tuturan kecil dengan cepat dan banyak dapat ditemukan fakta yang diperlukan; (c) masalah bunyi telah banyak dikaji dalam studi linguistik sehingga telah menjadi kajian yang sangat mapan. (d) perubahan bunyi itu beraturan dan dapat memberi indikasi hubungan di antaranya (Hock, 1988:573).

Tataran leksikal merupakan salah satu aspek penting dalam studi komparatif. Hal tersebut tampak terutama pada pengamatan tingkat awal dalam upaya pengelompokan antarbahasa sekerabat. Dengan menggunakan bukti-bukti kuantitatif yang lebih berorientasi pada pengamatan sekilas pada sejumlah kosakata dasar dapat ditentukan kelompok bahasa-bahasa sekerabat berdasarkan prosentasenya, sedangkan tataran fonologis dapat dipakai pada tingkat 
lanjutan untuk menentukan pengelompokan protobahasa. Berdasarkan perubahan bunyi secara teratur yang terjadi pada masingmasing bahasa kerabat dapat disusun kaidah-kaidah korespondensi fonem (Dyen, 1978 dan Bynon, 1979:25).

Pada dasarnya inti dari upaya penelusuran terhadap hubungan kekerabatan suatu bahasa, baik untuk tujuan pengelompokan bahasa (subgrouping) maupun penelitian asal bahasa, adalah penemuan terhadap bukti-bukti yang meyakinkan, yang terdapat dalam setiap bahasa yang diperbandingkan. Bukti-bukti tersebut dapat bersifat kuantitaif dan kualitatif. Bukti kuantitatif adalah dalam bentuk sejumlah kosakata kerabat (cognate set) yang berkaitan dengan retensi bersama (shared retention). Bukti kualitatif berupa inovasi bersama (shared inovation) serta korespondensi fonologis (Crowley, 1983; Jeffers dan Lehiste, 1979:1-16).

\section{Istilah dalam LHK}

\section{Pengelompokan Genetis}

Pengelompokan genetis adalah penelusuran subkelompok bahasa turunan dari kelompok bahasa yang lebih besar, berdasarkan hipotesis pohon kekerabatan, berdasarkan korespondensi bunyi yang ditetapkan dengan hukum perubahan bunyi yang beraturan. Hipotesis ini beranggapan bahwa moyang bahasa berbelah secara ber- turut-turut dan pada setiap tahapan terjadi perubahan yang mengakibatkan pembelahan lebih lanjut atau berkembang biak dengan proses dan caranya sendiri. (Jeffers dan Lehiste, 1979:27-31). Lebih lanjut dikatakan bahwa asumsi perkembangan spesies moyang bahasa yang melahirkan bahasa-bahasa turunan itu dapat ditelusuri kembali dengan menggunakan metode komparatif yang berdasarkan atas hipotesis keterkaitan dan keteraturan.

\section{Rekonstruksi Protobahasa}

Rekonstruksi protobahasa adalah penelusuran dan pembentukan kembali unsur-unsur warisan bahasa asal yang yang telah hilang melalui bentuk evidensi bahasa -bahasa turunan (berkerabat) yang sekarang masih hidup (Hock, 1988:581); Crowley, 1992:164; Arlotto:10). Penelusuran dan pembentukan kembali unsur warisan itu dapat dilakukan berdasarkan asumsi bahwa bahasa-bahasa sekerabat banyak menyimpan dan mengubah unsur warisan dengan kaidah dan berbagai cara (Dyen, 1978:35).

\section{Retensi}

Retensi adalah unsur warisan baik bentuk maupun arti yang tertinggal atau bertahan pada bahasa-bahasa turunan sama, dengan yang terdapat pada protonya (Anderson, 1979:103; Crowley, 1992:164). 


\section{Inovasi}

Inovasi adalah unsur warisan dari bahasa asal yang telah mengalami perubahan pada bahasa sekarang (Anderson, 1979:104). Bila terjadi perubahan pada kelompok bahasa turunan tertentu dan tidak terjadi pada kelompok bahasa lain dalam perkembangannya, maka disebut inovasi bersama yang ekslusif (exclusively shared lingistic innovation) (Greenberg, 1957:49).

\section{Kognat}

Kognat adalah kata-kata kerabah yang bentuk fonetik dan artinya sama atau mirip. (Jeffers dan Lehiste, 1979:167). Menurut Keraf (1984:36) kognat atau katakata kerabat adalah perangkat kata seasal yang memiliki kesamaan atau kemiripan bentuk dan arti.

\section{Korespondensi Bunyi}

Korespondensi bunyi atau kesepadanan bunyi adalah kesejajaran bunyi pada posisi yang sama yang terdapat pada bahasa-bahasa turunan berdasarkan kata dasar yang dikumpulkan dalam penelitian. Kesejajaran ini terlihat pada kesamaan atau kemiripan bentuk dan arti (Hock, 1988:557-558)

\section{Leksikostatik}

Leksikostatistik sebagai salah satu metode terkadang diperlakukan sarana atau berbeda metode glotokronologi. Bila disimak dari segi sasaran akhir yang akan dicapai, kedua metode ini harus dipandang sebagai dua hal yang berbeda. Tetapi bila dilihat dari kenyataan, tampak bahwa kedua hal/metode ini memiliki keterkaitan yang erat sekali (saling melengkapi satu sama lain) sehingga tidak ada alasan yang kuat untuk menganggap kedua hal tersebut berbeda. Selanjutnya. kedua istilah ini tidak dibedakan dalam pembahasan makalah ini dan dipakai satu istilah yang melingkupi keduanya yakni leksikostatistik.

Leksikostatistik sebagai salah satu metode pengelompokan bahasa telah banyak dipakai oleh para pakar/ahli bahasa di dunia ini. Metode ini memakai statistik yang berupa angka-angka sebagai dasar pemilihannya. Metode tersebut berusaha menemukan hubungan kekerabatan dua bahasa atau lebih dengan memperhitungkan unsur-unsur persamaan yang ada pada kosakatanya.

Menurut Nothofer ( 1990) metode leksikostatistik memiliki beberapa keunggulan bila dibandingkan metodemetode lain. Keunggulan-keunggulan yang dimaksud adalah antara lain (l) sebagai daftar kosakata dasar yang cepat dapat menentukan hubungan kekerabatan satu bahasa (bahasa sekerabat), (2) sebagai alat pengelompokan bahasa/dialek yang sekerabat yang proto bahasanya tidak begitu tua/ 
kuno, dan (3) sebagai alat/metode pengelompokan yang dapat digunakan pada tahap awal untuk menentukan klasifikasi bahasa.

Selanjutnya, Nothofer

menetapkan tiga asumsi dasar metode leksikostatistik, yakni (l) kosakata dasar diganti dengan kecepatan yang sama pada semua bahasa dalam waktu yang sama. Menurut asumsi ini bahwa setiap 1000 tahun sekitar 18 - 20 7\% kosakata dasar yang berubah dan berlaku umum pada semua bahasa secara serentak, (2) semua kosakata terdapat yang terdapat pada daftar kosakata dasar kemungkinan besar kata-kata itu terganti secara serentak, dan (3) ada yang dinamakan kosakata dasar yaug dianggap berlaku umum pada setiap bahasa di dunia.

Cara kerja leksikostatistik mengikuti pola-pola yang dikemukakan oleh Keraf (1990) yakni (1) mengumpulkan sejumlah kata dari kosakata dasar dan (2) menentukan pasangan kosakata dasar yang sekerabat. Selanjutnya, upaya menentukan kosakata dasar yang sekerabat mengikuti langkah-langkah yang dikemukakan oleh Keraf (1990) yakni (1) mencari kosakata yang bukan dari bahasa kata pinjaman. (2) mengambil morfem tunggal bebas saja dengan mengisolasi semua morfem terikat, dan (3) membandingkan semua pasangan kata untuk menentukan pasangan kata yang sekerabat dengan berdasarkan rekurensi, ko -okurensi, dan analogi. Upaya menentukan pasangan kata yang sekerabat itu dilakukan dengan mengindefikasi semua pasangan kata yang mirip/sama. pasangan kata yang mirip secara fonetis. Pasangan kata yang berkorespondensi bunyi dan pasangan kata yang hanya memiliki perbedaan satu fonem pada satu morfem.

\section{Rumus Leksikostatistik}

Ada tiga rumus dalam metode leksikostatistik yang sangat penting diketahui, yakni (1) rumus yang menentukan tingkat persentase hubungan kekerabatan, (2) rumus yang mencari waktu pisah, dan (3) rumus yang mencari jangka kesalahan. Ketiga rumus tersebut akan dijelaskan secara singkat berikut ini.

\section{Rumus Persentase Hubungan Kekera- batan}

Tingkat hubungan kekerabatan dua bahasa atau lebih dapat diketahui dengan memakai : diketahui dengan menerapkan rumus berikut:

$$
\begin{aligned}
\mathrm{H}=\frac{\mathrm{J}}{\mathrm{G}} \times 100 \% & \\
\text { Keterangan: } \mathrm{H} & =\text { Hubungan kekerabatan } \\
\mathrm{J} & =\text { Jumlah kata kerabat, } \\
\mathrm{G} & =\text { Glos (item) }
\end{aligned}
$$




\section{Rumus Waktu Pisah}

Waktu pisah dua bahasa atau lebih dapat diketahui dengan menerapkan rumus berikut:

a.Untuk menghitung waktu pisah antara tiga bahasa di Sulawesi Tenggara digunakan rumus:

$$
t=\frac{\log c}{2 \log r}
$$

keterangan:

$\mathrm{t}=$ lama waktu pisah dalam satuan ribu tahun

$\mathrm{c}=$ persentase kata-kata yang berkerabat dari dua bahasa

$r=$ indeks retensi yaitu persentase katakata yang sekerabat yang dianggap tetap ada seribu tahun setelah kedua bahasa itu berpisah dari bahasa purbanya.

b.Menghitung lama waktu pisah II menggunakan rumus

$$
t 1=\frac{\log c+\sqrt{c}(1-c) / n}{2 \log r}
$$

keterangan:

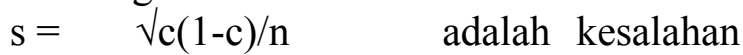
standar dalam persentase kerabat

$\mathrm{c}=$ persentase kata-kata kerabatdariduabahasa

$\mathrm{n}=$ jumlah kata yang dibandingkan (keraf, 1984:130).

keterangan:

$\mathrm{t}=$ lama waktu pisah dalam satuan ribuan

$\mathrm{t} 1=$ lama waktu pisah II

Ada beberapa terminologi yang biasa dipakai oleh para pakar/peneliti bahasa yang berkaitan dengan persentase kata kerabat. Terminologi-terminologi tersebut antara lain:

\section{Rumus Menghitung Jangka Kesalahan}

Agar kesalahan perhitungan statistik tidak terjadi, perlu diberikan etimasi bahwa suatu hal terjadi bukan dalam waktu tertentu. Dengan demikian dalam angka waktu tertentu tersebut, pada saat itulah terjadi akumulasi perbedaan dua bahasa atau lebih yang lambat laut semakin tinggi yang mengakibatkan akan terjadi perpisahan bahasa (Keraf, 1990).

Statistik memiliki tiga asumsi yang dikembangkan untuk mencegah akan terjadinya salah perhitungan Ketiga asumsi tersebut, yakni (1) $70 \%$ (0.7) mengandung kebenaran. (2) $50 \%$ (0.5) mengandung kebenaran, dan (3) 90 (0.9) mengandung kebenaran. Nurul (1990) bahwa semakin tinggi kepastian kebenaran semakin besar jangka tahunnya, sebaliknya bahwa semakin rendah kepastian kebenaran semaakin kecil jangka tahunnya.

Seperti dikatakan sebelumnya bahwa statistik mengakui adanya tiga kesalahan standar. Kesalahan standar itu biasanya dipilih jalan tengah, yakni $70 \%(0,7)$ mengandung kebenaran. Kesalahan standar tersebut diperhitungkan dengan rumus. 


\begin{tabular}{|c|c|c|c|c|}
\hline \multicolumn{3}{|c|}{ a. Smith (dalam Grimes, 1987) } & keluarga & $=36-12 \%$ \\
\hline dialek & \multicolumn{2}{|c|}{$=100-81 \%$} & \multicolumn{2}{|c|}{ rumpun $=12-4 \%$} \\
\hline bahasa & \multicolumn{2}{|c|}{$=80-75 \%$} & mikrofilum & $=4-1 \%$ \\
\hline subdialek & \multicolumn{2}{|c|}{$=75-60 \%$} & mesofilum & $=1-1 \%$ \\
\hline \multicolumn{3}{|c|}{ keluarga $=60-45 \%$} & \multicolumn{2}{|c|}{ c. Crowley ( 1987) } \\
\hline stok & \multicolumn{2}{|c|}{$=45-25 \%$} & dialek & $=81-100 \%$ \\
\hline superstok & \multicolumn{2}{|c|}{$=25-15 \%$} & bahasa & $=55-80 \%$ \\
\hline filum & \multicolumn{2}{|l|}{$=15-0 \%$} & subkeluarga & $=28-54 \%$ \\
\hline \multicolumn{3}{|c|}{ b.. Crowley (1987) dan Keraf (1990) } & \multicolumn{2}{|c|}{ keluarga $=13-27 \%$} \\
\hline dialek & \multicolumn{2}{|c|}{$=100-81 \%$} & \multicolumn{2}{|c|}{ rumpun $=5-12 \%$} \\
\hline bahasa & \multicolumn{4}{|c|}{$=81-36 \%$} \\
\hline \multicolumn{5}{|l|}{ d. $\operatorname{Keraf}(1990)$. } \\
\hline tingkat bahasa & \multicolumn{2}{|c|}{ waktu pisah dalam abad } & \multicolumn{2}{|c|}{ persentase kata kerabat } \\
\hline bahasa & \multicolumn{2}{|r|}{$0-5$} & \multicolumn{2}{|c|}{$100-81$} \\
\hline keluarga & \multicolumn{2}{|r|}{$5-25$} & \multicolumn{2}{|c|}{$81-36$} \\
\hline rumpun & \multicolumn{2}{|r|}{$25-30$} & \multicolumn{2}{|c|}{$36-12$} \\
\hline mikrofilum & \multicolumn{2}{|r|}{$50-75$} & \multicolumn{2}{|c|}{$12-4$} \\
\hline mesofilum & \multicolumn{2}{|r|}{$100 \mathrm{ke}$ atas } & \multicolumn{2}{|c|}{$1-1$} \\
\hline
\end{tabular}

\section{Metode Analisis Data dalam LHK}

Penelitian ini menggunakan metode analisis sinkomparatif dan diakomparatif historis (Lass, 1969:15). Metode sinkomparatif diterapkan sebelum menggunakan metode diakomparatif dengan maksud untuk menganalisis data bahasa-bahasa serumpun secara sinkronis. Metode ini digunakan berdasarkan kenyataan bahwa penelitian historis komparatif harus diawali dengan pendekatan sinkronis. Maksudnya, dalam membandingkan bahasa -bahasa berkerabat, sebelum dianalisis secara diakronis, bahasa-bahasa tersebut terlebih dahulu dianalisis secara sinkronis.
Metode analisis sinkomparatif lebih menekankan pada deskripsi fonem dan penemuan aspek perubahan fonologis secara deskriptif. Analisis ini bertujuan menemukan fonem, alofon beserta variannya, dan hubungan setiap fonem pada masing-masing sistem fonologi bahasa yang diteliti (Antonsen, 1990:297). Hal ini penting dilakukan untuk dijadikan landasan asumsi bahwa bahasa yang diteliti merupakan bahasa berkerabat, bukan bahasa yang sama dan bukan pula bahasa yang tidak berkerabat sama sekali (Martinet, 1955 dan Maulton, 1961 dalam Fisiak, ed, 1985). 
Metode analisis diakomparatif digunakan sebagai langkah lanjutan untuk membandingkan semua bahasa berkerabat yang diteliti secara diakronis. Cara kerja diakronis dilakukan bertahap. Pertama, data dalam bentuk daftar 200 kosakata dasar Swadesh dianalisis secara kuantitatif dengan menggunakan teknik leksikostatistik. Dengan teknik ini dapat diperoleh jumlah persentase kognat masing-masing bahasa (bandingkan Crowley, 1987:190). Berdasarkan angka persentase kognat antarbahasa dapat ditetapkan anggota kelompok yang bersifat sementara dari bahasa-bahasa yang diteliti. Kedua, data dianalisis secara kualitatif dengan memperhatikan (1) pasangan kata yang semua fonemnya identik, (2) pasangan yang memiliki korespondensi fonemis, (3) pasangan yang memiliki kemiripan secara fonetis, (4) pasangan yang mempunyai satu fonem beda. Keraf (1991) menyarankan tiga langkah berikut yang perlu ditempuh dalam merekonstruksi fonem-fonem bahasa kerabat: (a) mencatat semua korespondensi fonemis kelompok bahasa yang dibandingkan, (b) membandingkan unsur-unsur yang menunjukkan kontras dalam lingkungan yang lebih luas dan mencari pasanganpasangan baru untuk memperkuat temuan yang diperoleh dengan cara pertama, (c) merekonstruksi setiap fonem dari kata yang dibandingkan. Berdasarkan analisis kualiti- taif tersebut silsilah kekerabatan bahasabahasa yang diteliti ditetapkan secara definitif.

Analisis data dalam penelitian ini mengikuti urutan cara kerja yang mengacu pada tahapan dalam pencapaian tujuan penelitian. Sebagaimana yang dikemukakan di depan, bahwa tujuan penelitian ini meliputi pembuktian isolek, pengelompokan, dan rekonstruksi. Mengacu kepada hal itu, maka cara kerja penelitian ini menggunakan teknik-teknik seperti diuraikan berikut ini.

\section{Teknik Leksikostatistik}

Leksikostatistik adalah salah satu teknik pengelompokan bahasa-bahasa atau dialek yang mengutamakan perhitungan kata-kata secara statistik untuk mengetahui jumlah kesamaan kata-kata kerabat yang diperbandingkan (Grimes, 1987 dalam Mead 1999). Leksikostatistik berisikan daftar kosakata dasar setiap bahasa yang akan diperbandingkan. Morris Swadesh mengusulkan 200 kosakata dasar yang universal, yang meliputi kata-kata ganti, kata bilangan, kata-kata anggota badan (sifat dan aktivitasnya), alam dan sekitarnya dan alat-alat budaya sehari-hari.

Leksikostatistik sebagai salah satu teknik pengelompokan bahasa telah banyak dipakai oleh para pakar/ahli bahasa di dunia ini. Teknik ini memakai statistik 
yang berupa angka-angka sebagai dasar pemilahannya. Teknik tersebut berusaha menemukan hubungan kekerabatan dua bahasa atau lebih dengan memperhitungkan unsur-unsur persamaan yang ada pada kosakatanya.

Menurut Nothofer (1990) teknik leksikostatistik memiliki beberapa keunggulan bila dibandingkan metodemetode lain. Keunggulan-keunggulan yang dimaksud adalah antara lain (1) sebagai daftar kosakata dasar yang cepat dapat menentukan hubungan kekerabatan satu bahasa (bahasa kerabat), (2) sebagai alat pengelompokan bahasa/dialek yang sekerabat yang protobahasanya tidak begitu tua/ kuno, dan (3) sebagai alat/metode pengelompokan yang dapat digunakan pada tahap awal untuk menentukan klasifikasi bahasa.

Selanjutnya, Nothofer

(1990) menetapkan tiga asumsi dasar metode leksikostatistik, yakni (1) kosakata dasar diganti dengan kecepatan yang sama pada semua bahasa dalam waktu yang sama. Menurut asumsi ini bahwa setiap 1000 tahun sekitar 18-20\% kosakata dasar yang berubah dan berlaku umum pada semua bahasa secara serentak, (2) semua kosakata dasar yang terdapat pada daftar kosakata dasar kemungkinan besar kata-kata itu berganti secara serentak, dan (3) ada yang dinamakan kosakata dasar yang dianggap berlaku umum pada setiap bahasa di dunia. Cara kerja leksikostatistik mengikuti polapola yang dikemukakan oleh Keraf (1990) yakni, (1) mengumpulkan sejumlah kata dari kosakta dasar, dan (2) menentukan pasangan kosakata dasar yang sekerabat. Selanjutnya, upaya menentukan kosakata dasar yang sekerabat mengikuti langkahlangkah yang dikemukakan oleh Keraf (1990) yakni, (1) mencari kosakata yang bukan dari bahasa/kata pinjaman, (2) mengalami morfem tunggal/bebas saja dengan mengisolasi semua morfem terikat, dan (3) membandingkan semua pasangan kata untuk menentukan pasangan kata yang sekerabat dengan berdasarkan rekurensi, ko -okurensi, dan analogi. Upaya menentukan pasangan kata yang sekerabat itu dilakukan dengan mengidentifikasi semua pasangan kata mirip/sama, pasangan kata yang mirip secara fonetis, pasangan kata yang berkorespondensi bunyi, dan pasangan kata yang hanya memiliki perbedaan satu fonem pada satu fonem.

Rumus Persentase Hubungan Kekerabatan Tingkat hubungan kekerabatan dua bahasa atau lebih dapat diketahui dengan memakai rumus sebagai berikut

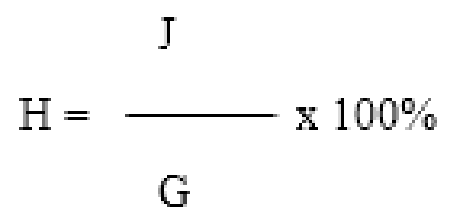


Keterangan:

$$
\begin{array}{ll}
\mathrm{H} & =\text { Hubungan kekerabatan } \\
\mathrm{J} & =\text { Jumlah kata kerabat, } \\
\mathrm{G} & =\text { Glos (item) }
\end{array}
$$

Teknik ini dipergunakan untuk membuktikan isolek-isolek di pulau Pantar sebagai beda bahasa atau beda dialek. Setelah didapatkan hasil persentase kognat keempat isolek tersebut, maka langkah selanjutnya adalah pembuktian isolek-isolek yang beda bahasa dan yang beda dialek.

Teknik ini pula dipergunakan untuk mengelompokkan bahasa-bahasa di pulau Pantar Nusa Tenggara Timur dilakukan berdasarkan bukti-bukti kuantitatif dan bukti-bukti kualitatif. Pengelompokan bahasa berdasarkan pada bukti-bukti kuantitatif menggunakan teknik Leksikostatistik. Bukti-bukti kuantitatif semua bahasa yang diteliti itu dikumpulkan dengan menggunakan daftar 200 kosakata dasar Swadesh (yang direvisi Blust, 1980). Dengan menggunakan metode ini, buktibukti kuantitatif dalam bentuk kemiripan dan kesamaan kosakata seasal dari setiap bahasa yang diperbandingkan dapat dihitung. Penghitungan jumlah persentase berdasarkan jumlah pasangan kosakata seasal dibagi jumlah gloss yang terisi kali seratu persen. Berdasarkan angka persentase itu dapat diketahui tingkat semua bahasa disekitarnya. Berdasarkan itu pula silsilah kekerabatan bahasa-bahasa itu dapat disusun.

Pengelompokan terhadap bahasabahasa di Pantar itu masih bersifat sementara dan belum tuntas. Untuk memperoleh ketuntasan pengelompokan bahasa itu diperlukan bukti-bukti kualitatif. Bukti-bukti kualitatif itu dapat berfungsi ganda. Pertama, untuk memperkuat pengelompokan yang telah ditetapkan berdasarkan buktibukti kuantitatif, jika ternyata hasil pengelompokannya saling mendukung. Kedua, jika berdasarkan bukti-bukti kualitatif yang menghasilkan pengelompokan yang bertentangan dengan pengelompokan sebelumnya, maka bukti-bukti kualitatif berfungsi menggugurkan pengelompokan yang berdasarkan pada bukti-bukti kuantitatif, sekaligus pengelompokan yang berlandaskan pada bukti-bukti kualitatif itu ditetapkan sebagai pengelompokan definitif (Blust, 1981). Bukti-bukti kualitatif yang diperlukan itu dikumpulkan dengan menggunakan daftar Holle dengan 1800 kata. Bukti-bukti kualitatif itu berwujud fakta-fakta kebahasaan yang tergolong sebagai unsur-unsur inovasi bersama yang eksklusif. Hakikat pengelompokan yang bersifat kualitatif pada tahapan ini adalah upaya penemuan kemiripan dan kesamaan unsur-unsur kebahasaan yang inovatif dan ekslusif baik tataran fonologi maupun leksikal pada bahasa-bahasa yang diteliti. 
Penemuan kemiripan dan kesamaan inovasi segi fonologi dapat ditelusuri pada kesamaan pola atau kaidah perubahan fonem yang ada pada bahasa-bahasa itu. Pada tataran leksikal, penemuan kemiripan dan kesamaan inovasi itu tampak pada kemiripan dan kesamaan kosakata seasal yang hanya dimiliki oleh kelompok atau subkelompok bahasa-bahasa itu. Ciri-ciri yang ditemukan itu dihubungkan dan dibandingkan antarsesamanya (internal) dan di luar kelompok bahasa itu (eksternal) dengan cermat. Semua itu, kemudian disarikan dalam bentuk klasifikasi (a) bukti penyatu kelompok, dan (b) bukti pemisah kelompok sekaligus penyatu subkelompok. Berdasarkan bukti penyatu kelompok dan bukti pemisah kelompok yang bersifat kualitatif itulah tinggkat keeratan kelompok bahasa itu ditetapkan dalam bentuk garis silsilah yang definitif.

\section{Teknik Rekonstruksi}

Setelah pengelompokan bahasa ditetapkan, langkah selanjutnya adalah penemuan protobahasa pulau Pantar dan protobahasa di bawahnya. Teknik yang digunakan adalah teknik rekonstruksi, baik rekonstruksi fonologi maupun rekonstruksi leksikal. Cara kerja rekonstruksi protobahasa dilaksanakan secara induktif yang dikenal dengan pendekatan darai bawah ke atas (Bottom-up Reconstruction). Teknik ini digunakan mengacu pada studi bahasa $\mathrm{Au}-$ tronesia pertama kali, ketika bahasa-bahasa Austronesia Barat (Tagalog, Jawa, dan Batak Toba) dibandingkan untuk merekonstruksi protobahasa Indonesia (Dempwollf, 1938). Langkah penetapan protofonem dilakukan dengan cara penetapan protofonem demi protofonem. Setiap protofonem ditemukan melalui (a) penelusuran jumlah perangkat kosakata seasal yang menunjang penentuan protofonem tertentu yang direkonstruksi, (b) pengamatan korespondensi fonem dan penetapan formulasi sejumlah kaidah perubahan bunyi, dan (c) penetapan etimon-etimon protobahasa dalam leksikal (bandingkan Fernandez, 1996:30). Cara kerja tersebut mengikuti urutan langkah rekonstruksi fonologi terlebih dahulu, kemudian dilanjutkan dengan rekonstruksi leksikal. Cara kerja itu diuraikan sebagai berikut.

\section{Teknik Rekonstruksi Fonologi}

Metode rekonstruksi khususnya fonologi pada hakikatnya proses penemuan dan pemerian proto fonem serta sistem fonologi protobahasa Kaera, Teiwa, Hamma, dan Tude. Proses ini ditempuh sebagai langkah persiapan menuju proses rekonstruksi leksikal. Langkah-langkah yang ditempuh dalam rekonstruksi fonologi meliputi (a) penetapan wujud proto fonem beserta lingkungan yang dimasukinya; (b) 
perumusan pantulan fonem proto bahasa pada bahasa-bahasa Kaera, Teiwa, Hamma, dan Tude yang dapat diamati dalam korespondensi bunyi berdasarkan padanan kosakata seasal; (c) perumusan kaidah korespondensi fonem antar bahasa itu berdasarkan pantulan fonem proto bahasa Kaera, Teiwa, Hamma, danTude

\section{Teknik Rekonstruksi Leksikal}

Rekonstruksi leksikal bertujuan untuk menemukan perangkat protokata yang memiliki makna (tertentu) yang sama atau mirip pada bahasa Kaera, Teiwa, Hamma, dan Tude sebagai bahasa yang diperbandingkan (Dyen, 1975:7). Rekonstruksi leksikal dilaksanakan setelah rekonstruksi fonologi dilakukan. Meskipun dilakukan kemudian, rekonstruksi keduanya tidak dapat dipisahkan. Dalam rekonstruksi fonologi harus melibatkan kata, melalui kosakata seasal itulah fonem dan perubahannya ditemukan. Setiap fonem dengan varian-variannya hanya dapat muncul dan secara gradual berubah, dalam struktur kata (Robinson, 1977:70).

\section{SIMPULAN}

Berdasarkan hasil pembahasan, maka dapat disimpulkan bahwa pembuktian hubungan kekerabatan dan keseasalan itu pada umumnya bertolak dari pengelompokan bahasa-bahasa dan rekonstruksi protobaha- sanya. Pengelompokan adalah penentuan bahasa-bahasa dalam suatu susunan atau protokerabat (family tree). Selanjutnya rekonstruksi protobahasa adalah penetapan satuan-satuan kebahasaan sebagai protobentuk. Dengan demikian, melalui pengelompokan dan rekonstruksi dapat diperoleh kejelasan hubungan kekerabatan dan keseasalan sesuai dengan jenjang struktur dan silsilah kekerabatan bahasa.

\section{UCAPAN TERIMAKASIH}

Penulis mengucapkan terima kasih kepada Mitra Bestari atas masukan-masukan yang telah diberikan untuk perbaikan substansi artikel saya ini.

\section{DAFTAR PUSTAKA}

Arlotto, Anthony. 1981. Introduction to Historical Linguistics. Boston: Houghton Mifflin.

Crowly. Terry. 1997. An Introduction to Historical Linguistic. Port Moresby: University of Papua New Guinea Press.

Fernandes, Inyo Yos. 1996. Relasi Historis Kekerabatan bahasa Flores. Kajian Linguistik Historis Komparatif terhadap sembilan bahasa di Flores. Flores: Nusa Dua

Kasseng, Syaharudin, Alimuddin D.P., Andi Mahmuddin and Rasdiana P. 1987. Pemetaan Bahasa-Bahasa di Sulawesi Tenggara. Jakarta: Pusat Pembinaan dan Pengembangan bahasa.

La Ino. 2004. "Pengelompokan Genetis Bahasa Blagar, Pura, dan Retta di Kabupaten Alor Provinsi Nusa Tenggara Timur." Tesis untuk Program Pascasarjana. Universitas Udayana.

La Ino. 2009. "Pelacakan Bahasa Tereweng di Kabupaten Alor Nusa Tenggara Timur" Makalah pada Seminar Internasional Bahasa, Sastra, dan Budaya di Kupang NTT. 
La Ino. 2013. Protobahasa Modebur, Kaera, dan Teiwa Bahasa Kerabat Non Austronesia di Pulau Pantar Nusa Tenggara Timur" Disertasi untuk Program Pascasarjana Universitas Udayana.

La Ino. 2013. "Austronesia dan Non Austronesia di Pulau Pantar Serta Hubungan Kekerabatannya dengan Bahasa Austronesia Di Flores Timur" Makalah Disajikan Pada Seminar Internasional "Bahasa, Sastra, dan Budaya Austronesia-NonAustronesia, Globalisasi, dan Revitalisasi” di Denpasar Bali 6 s.d. 7 November 2013

La Ino. 2014. "Bahasa Retta Bahasa Retta Dan Hubungan Kekerabatannya Dengan Bahasa Blagar Dan Pura Kabupaten Alor Provinsi Nusa Tenggara Timur" Makalah disajikan pada Konggres Internasional Masyarakat Linguistik Indonesia tanggal 19-22 Februari 2014 di Lampung.

La Ino. 2014. "Kekerbatan Bahasa Muna, Wolio, dan Tolaki dalam Angka: Suatu Analisis Leksikostatistik" dalam Jurnal Langua Vol. 4 No. 1 April 2014.

Lembaga Kajian Ekolinguistik; Medan

Mbete, Aron Meko. 1990. "Rekonstruksi Proto -Bali - Sasak - Sumbawa". Disertasi untuk Program Pascasarjana UI Jakarta. 